\section{Gas Composition and Temperature Affect Quality of Fresh-cut Fennel}

\author{
V.H. Escalona, F. Artés-Hernández, and F. Artés \\ Postharvest and Refrigeration Group, Department of Food Engineering, \\ Technical University of Cartagena, Paseo Alfonso XIII, 48, 30203 Cartagena, \\ Murcia, Spain \\ Additional index words. Foeniculum vulgare var. dulce, minimally processed, sensorial \\ quality, shelf life, browning
}

\begin{abstract}
Freshly harvested bulbs of fennel (Foeniculum vulgare var. dulce) 'Clio' were sliced at $5{ }^{\circ} \mathrm{C}$, dipped in $100 \mathrm{mg} \cdot \mathrm{L}^{-1} \mathrm{NaOCl}$ solution, and packaged in passive modified atmosphere packaging (MAP) by using trays covered and thermal sealed with unperforated or perforated polypropylene film. According to common commercial needs a shelf life of $14 \mathrm{~d}$ at 0 and $5^{\circ} \mathrm{C}$ was applied. The respiration rate of fresh-cut fennel was 1.3- to 1.7-fold higher at $5{ }^{\circ} \mathrm{C}$ than at $0{ }^{\circ} \mathrm{C}$, and was 1.4- to 1.8-fold higher than that reported for whole bulbs. MAP did not prevent the declines in SSC and TA that occurred during storage, while pH did not change. Water loss was lower than $0.1 \%$ in all treatments, and no decay or physiological disorders developed during storage. The gas compositions of 16 to $18 \mathrm{kPa} \mathrm{O}$ plus 2 to $4 \mathrm{kPa} \mathrm{CO}$ generated within the perforated packages at 0 and $5^{\circ} \mathrm{C}$ or 1.5 to $2 \mathrm{kPa} \mathrm{O}_{2}$ plus 18 to $20 \mathrm{kPa} \mathrm{CO}$ in unperforated packages at $5^{\circ} \mathrm{C}$ did not inhibit browning on the cut surface or other sensory changes of the slices. However, atmospheres in unperforated packages of 4 to $6 \mathrm{kPa} \mathrm{O}_{2}$ plus 10 to $14 \mathrm{kPa} \mathrm{CO}_{2}$ at $0{ }^{\circ} \mathrm{C}$ maintained the sensory quality like at harvest.
\end{abstract}

Over the last decade, fennel bulbs have developed in Spain as a relatively important vegetable. Cultivation of fennel with reasonable profits for producers is increasing in the Mediterranean southeastern areas of Spain due to the favorable agricultural conditions. Bulbs are mainly shipped to European countries (United Kingdom, Germany, France, Italy and others) while domestic consumption is still very low. Competitive results for cultivation of this vegetable have induced new research about production and postharvest handling (Artés et al., 2000; León et al., 1992; Maroto, 1995; Namesny 1993; Pico, 2001).

Low temperatures $\left(0\right.$ to $\left.1^{\circ} \mathrm{C}\right)$ high relative humidity (RH $90 \%$ to $95 \%$ ) and an intermediate air change should be used during storage, transport, and distribution (Namesny, 1993). Use of modified atmosphere packaging (MAP) as a physical treatment to avoid browning development on the butt end cut zone and on external leaves of fennel bulbs has been recommended (Artés et al., 2000, 2002b). Gas compositions with low $\mathrm{O}_{2}$ (3 to $5 \mathrm{kPa}$ ) and high $\mathrm{CO}_{2}(15$ to $20 \mathrm{kPa}$ ) levels decreased browning in the cut zone of whole 'Orion' fennel during 2 weeks of storage at 0 or $5{ }^{\circ} \mathrm{C}$ (Artés et al., 2000, 2002a). This physiological disorder is caused by polyphenol oxidase and other oxidative enzymes during cold storage of whole as well as of fresh-cut fruits and vegetables (Artés et al., 1998; Vamos-Vigyazo, 1981).

Received for publication 3 Dec. 2002. Accepted for publication 1 Sept. 2004. The authors are grateful to CYTED, Project XI.14 for a grant to V. H. Escalona and to Spanish CICYT, Project 1006/98, for financial support. Thanks are also due to CEBASCSIC (Murcia) and to FRUVEG Soc. Coop. (Torre Pacheco, Murcia) for providing facilities and fennel bulbs respectively.

1E-mail fr.artes@upct.es.
Operations involved in preparing fruits and vegetables as fresh-cut products generally increase their rate of deterioration. It is essential to keep these items at the lowest temperature feasible throughout the cool chain, usually in the range 0 to $5{ }^{\circ} \mathrm{C}$, for keeping quality and to extend their shelf-life. Additionally, modified atmospheres benefit fresh-cut products, mainly by reducing respiration rate, retarding microbial growth, and inhibiting disorders such as browning (Ahvenainen, 1996; Artés, 2000; Cantwell, 1992; Hamza et al., 1996). Fresh-processed fennel could be considered as a new product and its postharvest behavior has received very little attention in the scientific literature.

Fresh-cut fennel has been reported as being difficult to process, mainly due to its susceptibility to enzymatic browning, and a combination of partial vacuum packaging with a low concentration of citric acid and storage at $4{ }^{\circ} \mathrm{C}$ was effective in prolonging the shelf life of an unknown fennel cv. up to $10 \mathrm{~d}$ (Albenzio et al., 1998). However from the best of our knowledge no scientific information is available about optimal conditions for fresh-cut processing and distribution of fennel.

The aim of the present work was to study the fresh-cut processing of fennel and to determine the main quality attribute changes and losses throughout a relatively prolonged shelf life at two storage temperatures as affected by different atmospheres in MAP.

\section{Materials and Methods}

Preparation of fennel bulbs. 'Clio' fennel bulbs grown under Mediterranean Spanish climate were hand harvested by cutting the base with a sharp knife, and eliminating dirty and decayed external leaves. Bulbs were obtained from a commercial farm of Torre Pacheco (Murcia, Spain) in the middle of April and transported the same day over $30 \mathrm{~km}$ to the laboratory, where they were stored at $0{ }^{\circ} \mathrm{C}$. Next morning, bulbs were carefully selected to ensure that they were free from defects and with similar visual appearance and size. Individual weight was between 300 to $450 \mathrm{~g}$ and equatorial diameter ranged from 10 to $12 \mathrm{~cm}$. Before processing, sound bulbs were cleaned by dipping them for $1 \mathrm{~min}$ in a $50 \mathrm{mg} \cdot \mathrm{L}^{-1}$ aqueous $\mathrm{NaOCl}$ solution at $\mathrm{pH} 7.5$ and at about 20 ${ }^{\circ} \mathrm{C}$. In an isolated and clean room at $5{ }^{\circ} \mathrm{C}$, the bulbs were sliced in pieces of $8 \mathrm{~mm}$ thickness by cutting them perpendicular to the long axis with a commercial slicing machine (Jata, Slim model, Vizcaya, Spain). Immediately after cutting, the slices were dipped for $1 \mathrm{~min}$ in a $100 \mathrm{mg} \cdot \mathrm{L}^{-1}$ aqueous $\mathrm{NaOCl}$ solution at $5{ }^{\circ} \mathrm{C}$ and $\mathrm{pH} 7.5$, rinsed with tap water at $5{ }^{\circ} \mathrm{C}$ for $1 \mathrm{~min}$, and drained for $1 \mathrm{~min}$.

Respiratory activity. Rates of $\mathrm{CO}_{2}$ emission were determined by using a closed system (Escalona et al., 2002). Four glass jars each containing $200 \mathrm{~g}$ of fennel slices were placed in clean rooms at 0 or $5^{\circ} \mathrm{C}$ for $14 \mathrm{~d}$. The increases in $\mathrm{CO}_{2}$ were monitored daily after closing the jars for 2 to $3 \mathrm{~h}$. Gas samples were taken with a plastic syringe from the headspace. In order to avoid $\mathrm{CO}_{2}$ accumulation $(\leq 0.3 \%)$ (Watada et al., 1996) and to maintain a high RH within the jars, between each measurement a continuous air flow ( 3 to $4 \mathrm{~L} \cdot \mathrm{h}^{-1}$ and $95 \% \mathrm{RH}$ ) with a gas mixing system (Flowboard, Davis, Calif.) was applied. $\mathrm{CO}_{2}$ emission was determined by using a $0.5 \mathrm{~mL}$ gas sample injected in a gas chromatograph (GC) (GC-14B; Shimadzu, Tokyo, Japan) equipped with a thermal conductivity detector (TCD).

Modified atmosphere packages. Samples of $150 \pm 5 \mathrm{~g}$ of fennel slices were packed into polypropylene $(\mathrm{PP})$ trays of $17 \times 11 \times 4$ $\mathrm{cm}$ (Plasal-Isap, Alcira, Valencia, Spain) and covered with an antimist unperforated oriented PP film of $35 \mu \mathrm{m}$ thickness (OPP) (Plásticos del Segura S.L., Murcia, Spain), or with one (OPP1) or two (OPP2) perforations of 0.7 $\mathrm{mm}$ each. The film was heat sealed to the tray on the edges (model Befor; Barket, France) to generate a passive modified atmosphere. The film permeability at $23{ }^{\circ} \mathrm{C}$ and $75 \% \mathrm{RH}$ was 5000 to $6000 \mathrm{~mL} \cdot \mathrm{m}^{-2} \cdot \mathrm{d}^{-1} \cdot \mathrm{atm}^{-1}$ for $\mathrm{O}_{2}$ and 8000 to $12000 \mathrm{~mL} \cdot \mathrm{m}^{-2} \cdot \mathrm{d}^{-1} \cdot \mathrm{atm}^{-1}$ for $\mathrm{CO}_{2}$ (data provided by Plásticos del Segura S.L., Murcia, Spain). Five packages were used per film/temperature combition.

To simulate maximum commercial needs for shipment, distribution and retail sale, a storage period of $14 \mathrm{~d}$ was applied.

Gas composition within packages. Gas composition $\left(\mathrm{O}_{2}, \mathrm{CO}_{2}\right.$, and $\left.\mathrm{N}_{2}\right)$ within packages was monitored throughout storage by a GC (Perkin Elmer Autosystem, Norwalk, Conn.) equipped with a TCD. For analysis, a $0.5-\mathrm{mL}$ gas sample was taken from each package by using a plastic syringe through a silicone septum.

Chemical attributes evaluation. Slices randomly taken from each sample were squeezed with a commercial blender (Moulinex, Barcelona, Spain). The juice was analyzed for 
soluble solids content (SSC), $\mathrm{pH}$, and titratable acidity (TA). SSC was measured with a hand refractometer (Atago N1, Tokyo, Japan) and expressed as ${ }^{\circ} \mathrm{Brix}$ at $20^{\circ} \mathrm{C}$. The $\mathrm{pH}$ was determined by using a digital $\mathrm{pH}$ meter (Crison 501; Barcelona, Spain). For TA, $10 \mathrm{~mL}$ of juice was titrated with $0.1 \mathrm{~N} \mathrm{NaOH}$ to an endpoint of $\mathrm{pH}$ 8.1 (AOAC, 1984) and expressed as oxalic acid in $\mathrm{g} \cdot \mathrm{L}^{-1}$. Quality attributes were determined at the beginning and after shelf life.

Sensorial evaluation. A panel of five persons familiar with sensory properties of fennel evaluated visual appearance, aroma, flavor, and texture. A nine-point scale $(9=$ excellent, $7=$ good, 5 = acceptable, limit of marketability, 3 = poor, and $1=$ extremely poor) adapted from Kader et al. (1973) was used to score each sensory property. Sensorial panel evaluated a representative sample coming from each treatment.

Weight loss, decay, and browning evaluation. Weight loss was determined by using a scale (PC model; Mettler Instruments, Zurich, Switzerland) with an accuracy of $0.01 \mathrm{~g}$. Values were expressed as percentage of initial fresh weight. Decay and browning were subjectively evaluated by using the scale $(1=$ none, $2=$ slight, $3=$ moderate, $4=$ severe, $5=$ very severe). Slices that scored higher than 3 were considered as unacceptable for consumers (Escalona et al., 2002). Values correspond to a mean of five packages per treatment.

Statistical analysis. The experiment followed a completely randomized design (n $=5$ ). Statgraphic Plus version 2.1 software was used for analysis of variance and least significant difference test (at the 5\% level) to compare means.

\section{Results and Discussion}

Respiratory activity. Mean values of respiration rate $\left(\mathrm{CO}_{2}\right.$ production) of fennel slices were between 20 to $24 \mathrm{mg} \cdot \mathrm{kg}^{-1} \cdot \mathrm{h}^{-1}$ at 5 ${ }^{\circ} \mathrm{C}$ and between 14 to $16 \mathrm{mg} \cdot \mathrm{kg}^{-1} \cdot \mathrm{h}^{-1}$ at $0{ }^{\circ} \mathrm{C}$. Throughout the storage period a slight decline in respiratory activity at both temperatures was found. The respiration rate was 1.3- to 1.7-fold higher at $5{ }^{\circ} \mathrm{C}$ than at $0^{\circ} \mathrm{C}$. This result indicates 1.4-to 1.8-fold higher respiration rate than that reported for whole 'Clio' bulbs stored in air at $0{ }^{\circ} \mathrm{C}$, which reached moderate respiration rates of 9 to $10 \mathrm{mg} \cdot \mathrm{kg}^{-1} \cdot \mathrm{h}^{-1}$ (Artés et al., 2002a). This increase in the respiration rate due to processing agrees with results reported for other fresh-cut vegetables, which exhibit 1.2- to 7-fold higher respiration than the whole product, depending on the produce, cutting grade, and temperature (Ahvenainen, 1996; Artés, 2000; Brecht, 1995; Cantwell, 1992; Watada et al., 1990).

Modified atmosphere packaging. Gas composition within packages. No steady state was reached in unperforated OPP, and after 14 $\mathrm{d}$ of storage gas atmospheres were 4 to $6 \mathrm{kPa}$ $\mathrm{O}_{2}$ plus 10 to $14 \mathrm{kPaCO}$, at $0{ }^{\circ} \mathrm{C}$ and 1.5 to $2 \mathrm{kPa} \mathrm{O}_{2}$ plus 18 to $20 \mathrm{kPa} \mathrm{CO}_{2}$ at $5^{\circ} \mathrm{C}$ (Fig. 1). Differences in $\mathrm{O}_{2}$ and $\mathrm{CO}_{2}$ levels between 0 and $5{ }^{\circ} \mathrm{C}$ were very probably due to the greater respiratory activity of sliced fennel at 5 than at $0{ }^{\circ} \mathrm{C}$.

Levels of $\mathrm{O}_{2}$ and $\mathrm{CO}_{2}$ within packages were quite similar when OPP film with either 1 or 2 perforations were used. Steady state gas compositions were about 16 to $18 \mathrm{kPa} \mathrm{O}$ plus 2 to $4 \mathrm{kPa} \mathrm{CO}$ in both packages at 0 and $5{ }^{\circ} \mathrm{C}$ (Fig. 1). This atmosphere contrasts with the range commonly recommended (Cantwell, 1992) for fresh-cut vegetables ( 2 to $8 \mathrm{kPa} \mathrm{O}$ plus 5 to $15 \mathrm{kPa} \mathrm{CO}_{2}$ ), although the use of 1 or 2 perforations could be suggested when temperature abuse (over $5{ }^{\circ} \mathrm{C}$ ) during transport, distribution and, particularly, retail sale periods, could occur.

Chemical attributes. After storage in all treatments, a decrease in SSC was detected and no differences among them were found (Table 1). At the end of storage at both temperatures, except for a slight increase in both OPP treatments, no changes in $\mathrm{pH}$ levels compared to values at harvest were found (Table 1). After storage, the lowest TA was found in slices un-
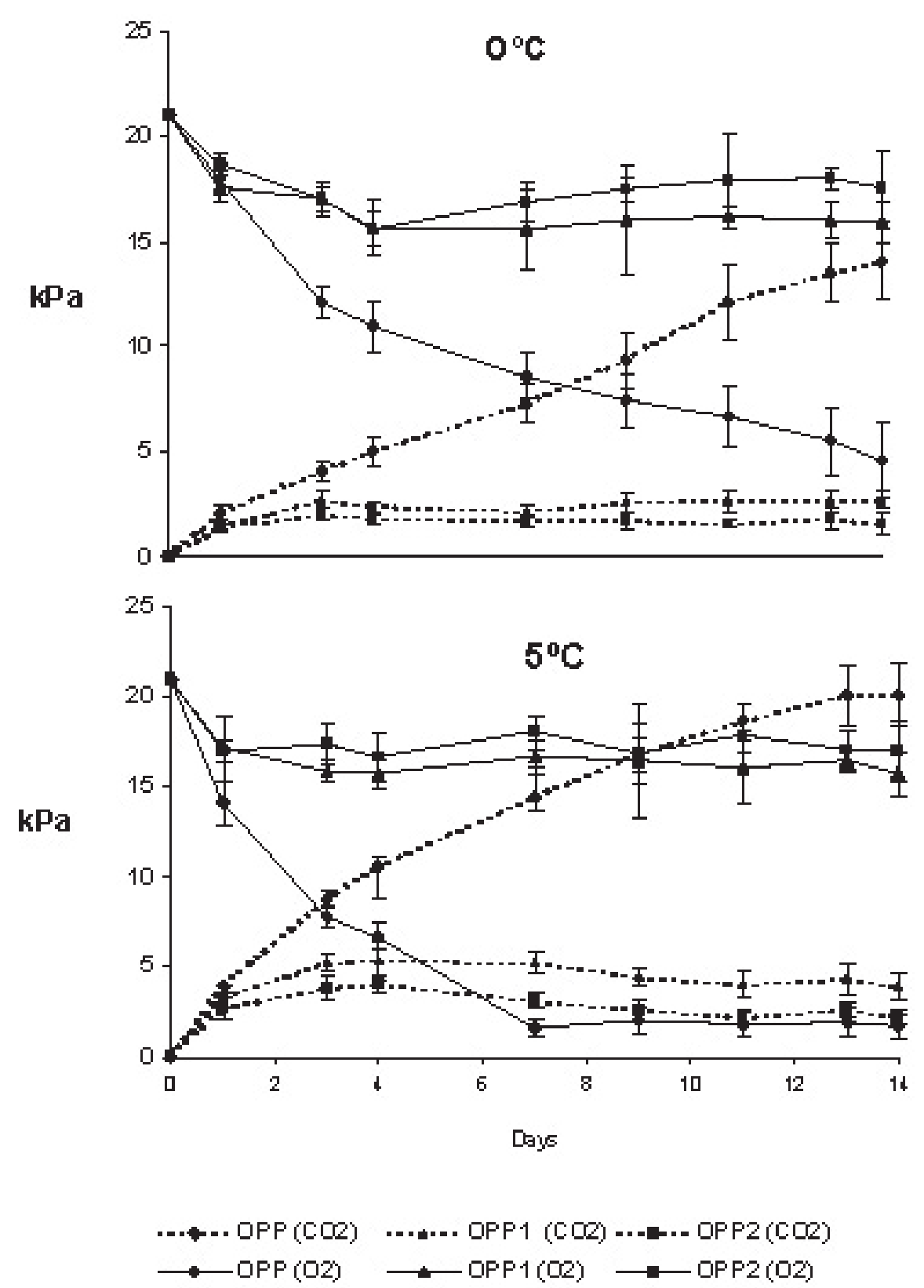

Fig. 1. Changes in $\mathrm{O}_{2}$ and $\mathrm{CO}_{2}$ levels in passive MAP storage of fresh-cut fennel during $14 \mathrm{~d}$ at 0 and $5^{\circ} \mathrm{C}$. Five repetitions of $150 \mathrm{~g}$ per treatment were used. Bars represent standard error. 
Table 1. Soluble solids content (SSC), $\mathrm{pH}$, and titratable acidity (TA) of fresh-cut fennel stored in passive MAP for $14 \mathrm{~d}$ at 0 or $5^{\circ} \mathrm{C}$.

\begin{tabular}{lccc}
\hline Treatment & $\begin{array}{c}\text { SSC } \\
\left({ }^{\circ} \text { Brix }\right)\end{array}$ & $\mathrm{pH}$ & $\begin{array}{c}\text { TA } \\
\text { (g of oxalic acid/L) }\end{array}$ \\
\hline $\begin{array}{l}\text { At harvest } \\
\text { After } 14 \mathrm{~d} \text { at } 0{ }^{\circ} \mathrm{C}\end{array}$ & $5.5 \mathrm{a}^{\mathrm{z}}$ & $6.2 \mathrm{~b}$ & $0.61 \mathrm{a}$ \\
$\quad$ OPP & $4.8 \mathrm{~b}$ & $6.4 \mathrm{a}$ & $0.42 \mathrm{c}$ \\
OPP1 & $4.6 \mathrm{~b}$ & $6.2 \mathrm{~b}$ & $0.48 \mathrm{bc}$ \\
OPP2 & $4.4 \mathrm{~b}$ & $6.2 \mathrm{~b}$ & $0.46 \mathrm{bc}$ \\
After 14 d at $5{ }^{\circ} \mathrm{C}$ & & & \\
$\quad$ OPP & $4.6 \mathrm{~b}$ & $6.4 \mathrm{a}$ & $0.44 \mathrm{c}$ \\
OPP1 & $4.6 \mathrm{~b}$ & $6.2 \mathrm{~b}$ & $0.53 \mathrm{~b}$ \\
OPP2 & $4.6 \mathrm{~b}$ & $6.2 \mathrm{~b}$ & $0.53 \mathrm{~b}$ \\
\hline
\end{tabular}

${ }^{ }$Data within a column followed by the same letter are not significantly different $(P \leq 0.05)$ according to $\operatorname{LSD}(\mathrm{n}=5)$.

${ }^{\mathrm{y}} \mathrm{OPP}=$ unperforated film; OPP 1 and OPP $2=1$ or 20.7 -mm perforations, respectively.

Table 2. Sensory attribute changes of fresh-cut fennel stored in passive MAP for $14 \mathrm{~d}$ at 0 or $5{ }^{\circ} \mathrm{C}$.

\begin{tabular}{lcllcc}
\hline Treatment & $\begin{array}{c}\text { Visual } \\
\text { appearance }\end{array}$ & Aroma & Flavor & Texture & $\begin{array}{c}\text { Browning on } \\
\text { the cut surface }\end{array}$ \\
$\begin{array}{l}\text { At harvest } \\
\text { After } 14 \mathrm{~d} \text { at } 0{ }^{\circ} \mathrm{C}\end{array}$ & $8.4 \mathrm{a}^{z}$ & $8.0 \mathrm{a}$ & $8.2 \mathrm{a}$ & $8.8 \mathrm{a}$ & $1.0 \mathrm{a}$ \\
$\quad$ & & & & & \\
OPPy & $8.4 \mathrm{a}$ & $7.6 \mathrm{ab}$ & $7.6 \mathrm{ab}$ & $8.0 \mathrm{ab}$ & $1.2 \mathrm{a}$ \\
OPP1 & $6.0 \mathrm{~b}$ & $5.6 \mathrm{c}$ & $6.8 \mathrm{~b}$ & $7.6 \mathrm{~b}$ & $2.0 \mathrm{a}$ \\
OPP2 & $5.0 \mathrm{~b}$ & $7.4 \mathrm{ab}$ & $6.6 \mathrm{~b}$ & $7.4 \mathrm{~b}$ & $2.2 \mathrm{a}$ \\
After $14 \mathrm{~d}$ at $5{ }^{\circ} \mathrm{C}$ & & & & & \\
OPP & $6.4 \mathrm{~b}$ & $7.0 \mathrm{~b}$ & $7.4 \mathrm{ab}$ & $7.6 \mathrm{~b}$ & $2.1 \mathrm{a}$ \\
OPP1 & $6.2 \mathrm{~b}$ & $6.0 \mathrm{bc}$ & $7.0 \mathrm{~b}$ & $7.8 \mathrm{ab}$ & $2.1 \mathrm{a}$ \\
OPP2 & $5.2 \mathrm{~b}$ & $6.4 \mathrm{bc}$ & $7.0 \mathrm{~b}$ & $7.2 \mathrm{~b}$ & $2.3 \mathrm{a}$ \\
\hline
\end{tabular}

${ }^{2}$ Data within a column followed by the same letter are not significantly different $(P \leq 0.05)$ according to $\operatorname{LSD}(\mathrm{n}=5)$.

${ }^{y} \mathrm{OPP}=$ unperforated film; OPP1 and OPP $2=1$ or $20.7-\mathrm{mm}$ perforations, respectively.

differences among perforated and unperforated OPP treatments were found.

Weight loss, decay, and browning. Weight loss was lower than $0.1 \%$ after $14 \mathrm{~d}$ at both 0 and $5{ }^{\circ} \mathrm{C}$. No physiological disorders nor decay developed at any time, although a slight browning on the cut surface occurred for slices in OPP1 and OPP2 packages at both temperatures and in unperforated OPP at $5{ }^{\circ} \mathrm{C}$ (Table 2). Results for browning development contrast with those reported by Albenzio et al. (1998), who considered enzymatic browning as the main cause of postharvest deterioration of fresh-cut fennel. This could be due to different sensitivities to browning of fennel cultivars. In fact, a higher sensitivity to browning of the butt end cut zone on whole bulbs of 'Orion' than that shown by whole 'Clio' bulbs during controlled atmosphere storage has been recently reported (Artés et al., 2002a).

These results suggest that low temperature maybe more important that altered atmosphere since a less extreme atmosphere at $0{ }^{\circ} \mathrm{C}$ was
Association of Official Analytical Chemists. 1984. Official methods of analysis, p. $414-420.14^{\text {th }}$ ed. Assn. Official Anal. Chem., Arlington,Va.

Artés, F. 2000. Productos vegetales procesados en fresco, p. 127-141. In: M. Lamúa (ed.). Aplicación del frío a los alimentos. Mundi-Prensa, Madrid Spain.

Artés, F., M. Castañer, and M.I. Gil. 1998. Enzymatic browning in minimally processed fruit and vegetables. Food Sci. Technol. Intl. 4:377-389.

Artés, F., V.H. Escalona, F. Artés-Hdez, and L. Luchsinger. 2000. Conservación de hinojo bajo atmósfera modificada. Rev. Iber. Tecnol. Postcosecha 2(2):194-199.

Artés, F., V.H. Escalona, and F. Artés-Hdez. 2002a. Quality and physiological changes of fennel under controlled atmosphere storage. Eur. Food Res. Technol. 214:216-220.

Artés, F., V.H. Escalona, and F. Artés-Hdez. 2002 b. Modified atmosphere packaging of fennel. J. Food Sci. 67:1550-1554.

Brecht, J.K. 1995. Physiology of lightly processed fruits and vegetables. HortScience 30:18-22.

Cantwell, M. 1992. Postharvest handling systems: Minimally processed fruits and vegetables, p. 277-282. In: A.A. Kader (ed.). Postharvest technology of horticultural crops. Univ. Calif.(Oakland) Publ. 3311.

Escalona, V.H., E. Aguayo, and F. Artés. 2003. Quality and physiological changes of fresh-cut kohlrabi. HortScience 38:1148-1152.

Hamza, F., F. Castaigne, C. Willemot, G. Doyon, and J. Makhlouf. 1996. Storage of fresh-cut romaine lettuce under controlled atmosphere. J. Food Qual. 19:177-188.

Kader, A.A., W.J. Lipton, and L.L. Morris. 1973. Systems for scoring quality of harvested lettuce. HortScience 8:408-409.

sphere at $5^{\circ} \mathrm{C}$.

\section{Conclusions}

The use of MAP with low $\mathrm{O}_{2}$ and high $\mathrm{CO}_{2}$ concentrations could be useful to avoid browning in fresh processed fennel. MAP with 2 to $6 \mathrm{kPa} \mathrm{O}_{2}$ plus 10 to $20 \mathrm{kPa} \mathrm{CO}$ at 0 and $5{ }^{\circ} \mathrm{C}$ maintained good quality of fennel slices, although the best results for keeping overall quality of fresh-cut 'Clio' fennel for $14 \mathrm{~d}$ was found in MAP of 4 to $6 \mathrm{kPa} \mathrm{O}_{2}$ plus 10 to 14 $\mathrm{kPaCO}$, at $0{ }^{\circ} \mathrm{C}$.

\section{Literature Cited}

Ahvenainen, R. 1996. New approaches in improving the shelf life of fresh-cut fruits and vegetables. Trends Food Sci. Technol. 7:179-186.

Albenzio, M., M.R. Corbo, and M. Sinigalia. 1998. Influenza del confezionamento sulla shellife di ortaggi di IV gamma. Industrie Alimentaria 37:341-350.
León, A.M., M.C. Vera, I. Rodríguez, and J.A. Marante. 1992. Ensayo de diferentes épocas de siembra y densidades de plantación en ciclos de otoño-invierno, en hinojo dulce. Agrícola Vergel. XI (125):328-333.

Maroto, J.V. 1995. Hinojo, p. 299-301. In: J.V. Maroto (ed.). Horticultura herbácea especial. Mundi-Prensa, Madrid, Spain.

Namesny, A. 1993. Hinojo, p. 257-262. In: A. Namesny (ed.). Postrecolección de hortalizas I. Horticultura S.L., Barcelona, Spain.

Pico, B. 2001. Hinojo, p. 178-181. In: F. Nuez and G. Yacer (eds.). La horticultura española. Horticultura S.L., Tarragona, Spain.

Vamos-Vigyazo, L. 1981. Polyphenol oxidase and peroxidase in fruits and vegetables. Crit. Rev. Food Sci. 15:49-127.

Watada, A.E., K. Abe, and N. Yamuchi. 1990. Physiological activities of partially processed fruits and vegetables. Food Technol. 44(5):116-122.

Watada, A.E., P.K. Nathanee, and A.M. Donna. 1996. Factors affecting quality of fresh-cut horticultural products. Postharvest Biol. Technol. 9:115-125. 